Rev. Inst. Med. trop. Säo Paulo

31 (1): 14-17, janeiro-fevereiro. 1989

\title{
Schistosoma mansoni: ACQUIRED RESISTANCE IN MICE BY IMPLANTATION OF YOUNG IRRADIATED WORMS INTO THE PORTAL SYSTEM (1)
}

Paulo Mareos Z. COFLho (2), Rómulo Teixeira de MELLo (3) \& Carlos Alberto P. TAVARES (4)

\begin{abstract}
SUMMARY
In two distinct experiments, immature $\mathbf{S}$. mansoni worms (LE strain. Belo Hori zonte, Brazil), aged 20 days, obtained from the portal system of white outbred mice, were irradiated with 14 and $4 \mathrm{Krad}$, respectively. Afterwards, the worms were directly inoculated into the portal vein of normal mice. Inoculation was performed with 20 irradiated worms per animal. Fifty days after inoculation, the mice that received 4 and $14 \mathrm{Krad}$-irradiated worms and their respective controls were infected with S. mansoni cercariae (LE strain), by transcutaneous route. Twenty days after this challenge infection, the animals were sacrificed and perfused for mature irradia ted (90-day-old) and immature (20-day old) worm counts. Analysis of the results showed that statistically significant protection against cercariae occurred in both groups with irradiated worms.
\end{abstract}

KEY WORDS: Schistosoma mansoni - irradiated worms - immunoprotection transplantation of worms.

\section{INTRODUCTION}

Acquired resistance in mice, which is always partial and never absolute, has been the subject of various reviews ${ }^{8.11}$ 12.12. Recently, and more closely related to the matter of the present study, is the comprehensive review elaborated by $\mathrm{DEAN}^{3}$. According to this review, the most consistent data with corroborative results were obtained by three major systems of immunization: 1. Through normal bisexual infection - the so called concomitant immunity: 2 . Through infection with irradiated cercariae and schistosomules, and 3 . Through heterologous antigens obtai- ned from Fasciola hepatica. On the other hand the pertinent literature shows different works that achieved to induce acquired immunity. through other approaches. However, these works have been discussed by several authors, that we re not able to corroborate the same results. In this way, immunoprotection has been obtained by unisexual infection, inoculation of antigens obtained from evolutive stages such as cerca riae, schistosomules, worms and eggs, and inocu lation of antigens from bacteria. snails, etc. Acquired immunity has been also obtained

(1) This work was supported, in part, by CNPq and FINEP. Brazil.

(2) Departamento de Parasitologia e Grupo Interdepartamental de Estudos sobre Esquistossomose IGIDE). ICB UFMG Caixa Postal 2486. CEP 30161 Belo Horizonte, MG, Brasil.

(3) Departamento de Análises Clínicas e Toxicológicas, Faculdade de Farmacia da UFMG e Grupo Interdepartamental de Estudos sobre Esquistossomose (GIDE), ICB UFMG, Belo Horizonte, MG. Brasil.

14) Departamento de Bioquimica Imunologia, ICB UFMG. Belo Horizonte. MG. Brasil. 
COELhO, P. M. Z.: MELLO, R. T. de \& TAVARES. C. A. P. - Schistosoma mansoni: acquired resistance in mice by implantation of young irradiated worms into the portal system. Rev. Inst. Med. trop. Sáo Paulo, 31(1): 14-17, 1989

through heterologous infections with other species of the genus Schistosoma. Nevertheless, the number of works carried out under this last re search line is still very reduced to allow more definite conclusions.

Concomitant immunity - the most effective and studied so far - presents different factors that contribute to its higher or lower manifestation, as follows: worm burden, duration of infection, infection route, and genetics of the host. The system involving irradiated cercariae and schis tosomules shows also different variables that interferes with the response. Thus, the resistance so produced depends on the immunizing worm burden, irradiation dose, immunization route, strain of mice, and strain of parasite used ${ }^{2 .}$.

In the present study, an attempt to obtain immunization through young irradiated worms, by using a strain of $\mathbf{S}$. mansoni that was not employed for this purpose as yet, and a stage of the parasite rarely used in irradiated schemes for immunization, has been made.

\section{MATERIAL AND METHODS}

The LE strain (Belo Horizonte, Brazil) of $\mathbf{S}$. mansoni was used in this research. This strain has been maintained at the laboratories of the "Grupo Interdepartamental de Estudos sobre Esquistossomose - GIDE" (Schistosomiasis Research Unit), Federal University of Minas Ge rais, Brazil, for more than twenty five years, and it has been used by different authors, as stated in hundreds of original articles published for the same period.

Twenty-day-old S. mansoni worms (LE strain, Belo Horizon te, Brazil) obtained from the portal system of mice, as described by BARBO SA et al. ${ }^{1}$, were irradiated by means of a Co-60 reactor, at the dose levels of 14 and $4 \mathrm{Krad}$ (not used to this purpose up till now), in two different experiments. About 20 irradiated worms were inoculated into the portal system of white out bred mice, according to the technique reported by ROCHA \& COELHO ${ }^{10}$. Fifty days after inoculation, the animals with irradiated worms and respective controls of the same cohort were in fected with normal cercariae of S. mansoni, transcutaneously. The mice that were inocula- ted with worms irradiated with $14 \mathrm{Krad}$ were infected with 50 cercariae, whereas the group infected with $4 \mathrm{Krad}$-irradiated worms were in fected with 100 cercariae. Twenty days after the challenge infection, all the animals were sacrificed and perfused for worm recovery, according to the technique prescribed by PELLEGRINO \& SIQUEIRA ${ }^{7}$. The difference in the development of the worms, related to their age (irradia ted $=90$ days; challenge infection $=20$ days , allowed the identification of the individuals from the two populations, easily.

\section{RESULTS}

As can be seen in Table 1, the immature worms irradiated with 14 and $4 \mathrm{Krad}$ were able to induce protection in mice against cercarial infection. Statistical analysis by means oi the Student's t test showed a significant difference between the worm recovery mean of the groups previously inoculated with irradiated worms and that one of their respective controls $(4$ Krads, $p<0.05 ; 14 \mathrm{Krad}, p<0.001$ ).

\section{DISCUSSION}

Considering the data presented in Table 1 , it can be seen that the animal groups which re ceived a prime infection with 20 immature worms, irradiated with 4 and $14 \mathrm{Krad}$, were able to acquire protection against cercarial challen ge.

In this way, DEAN et al. ${ }^{5}$ using the Puerto Rican Strain of S. mansoni achieved immuno protection through the inoculation of 105 twen ty-day-old worms (irradiated with $50 \mathrm{Krad}$ ) into the mesenteric veins of inbred mice. Nevertheless, the present paper and the Dean's mentioned pa per differ one of the other significantly. The strains of the parasite used were different, and the inocula employed by DEAN et al. ${ }^{5}$ were five times higher than those used in the present pa per, whereas they used an irradiation dose three times higher.

On the other hand, FORD et al. ${ }^{6}$ obtained protection against $\mathbf{S}$. mansoni cercariae, by ino culating 400 irradiated (20 Krad) worms, 11 days old, into the mesenteric veins of rats (Rattus norvegicus). These findings showed that young 
COELHO, P. M Z.: MELLO, R. T. de \& TAVARES, C A. P. - Schistosoma mansoni: acquired resistance in mice by implantation of young irradiated worms into the portal system Kev. Inst. Med. trop. Sä Paulo, 31 (1): 14.17. 1989 .

\section{TABLE 1}

Immunization of mice by inoculation of 20 young irradiated worms, twenty day-old, into the portal vein

\begin{tabular}{|c|c|c|c|c|c|}
\hline & \multirow{2}{*}{$\begin{array}{l}\text { Number of } \\
\text { cercariae } \\
\text { used } \\
\text { in the } \\
\text { challenge } \\
\text { infection }\end{array}$} & \multicolumn{2}{|c|}{$\begin{array}{l}\text { Mean and standard deviation of worm } \\
\text { recovery from the challenge infection }\end{array}$} & \multirow{2}{*}{$\begin{array}{l}\text { Mearis and standard } \\
\text { deviation of } \\
\text { irradiated } \\
\text { worm } \\
\text { recovery }\end{array}$} & \multirow{2}{*}{$\begin{array}{c}\text { Statistical } \\
\text { analysis } \\
\text { by the } \\
\text { Student's } \\
\text { t test } \\
\text { P< }\end{array}$} \\
\hline & & $\begin{array}{l}\text { Group of mice previously } \\
\text { inoculated with irradiated } \\
\text { worms } \\
\text { (Exp. I } 14 \mathrm{Krad} \\
\text { Exp. II } 4 \mathrm{Krad} \text { ) }\end{array}$ & $\begin{array}{l}\text { Control } \\
\text { group }\end{array}$ & & \\
\hline $\operatorname{Exp} I$ & 50 & $\begin{array}{c}18.93 \pm 4.97 \\
n=14\end{array}$ & $\begin{array}{c}1264=4.95 \\
n=14\end{array}$ & 0 & 0.001 \\
\hline Exp. II & 100 & $\begin{array}{c}25.00 \pm 9.42 \\
n=10\end{array}$ & $\begin{array}{c}35.20=9.40 \\
n \therefore 10\end{array}$ & $01 * \pm 0.32$ & 005 \\
\hline
\end{tabular}

* only 1 atypical adult. worm.

irradiated worms are very effective, when used as immunizing material. However, the rat is considered a "rion permissible host" and, there. fore, it differs widely from the mouse, which is believed to be a "permissible host". Furthermo re, the amount and the age of the irradiated worms used for inoculum differred significantly from those ones used in the present study, as well as from those used by DEAN et al. ${ }^{5}$

Finally, the results presented here, and the findings obtained by other authors engaged in this research line, showed that young irradiated worms inoculated into the portal system of the vertebrate host could promote immunoprotection against cercarial challenge. Thus, further researches will be necessary to clear up some basic aspects related to the immunizing process. Moreover, considering the pertinent literature. it is evident that more detailed studies should be carried out in order to find out how long the immunity induced by the use of irradiated para sites endures in the host.

\section{RESUMO}

Schistosoma mansoni: resistência adquirida em camundongos pela implantaçâo de vermes jo. vens irradiados no sistema porta.

Em dois experimentos distintos, vermes imaturos de Schistosoma mansoni, com 20 dias de idade, obtidos do sistema porta de camun dongos albinos, foram irradiados com 14 e $4 \mathrm{Krad}$ e posteriormente inoculados diretamente na veia porta de camundongos normais. Cada animal, de cada experimento especifico, recebeu 20 vermes irradiados. Decorridos 50 dias de inoculação, os carnundongos com os vermes irradiados com 4 e $14 \mathrm{Krad}$ e seus respectivos controles foram infectados pela via transcutànea, com cer. cárias da cepa LE de Schistosoma mansoni. No 20: dia após esta infecção desafio, os camundongos foram sacrificados e perfundidos para as contagens dos vermes maduros irradiados (90 dias de idade) e imaturos ( 20 dias de idade).

A análise dos resuitados mostrou que ocorreu proteçāo, estatísticamente significativa, contra cercárias nos grupos previamente inoculados com verrnes irradiados corn as doses de 4 e $14 \mathrm{Krad}$

\section{ACKNOWLEDGEMENTS}

The Authors gratefully acknowledge Mrs. Vera de Paula Ribeiro for translating the manuscript, and the technical assistance of Mr. Alberto Geraldo dos Santos, Mrs. Alice Neni Faria, Miss Zenir de Souza, Mr. José de Souza Filho, Mr. Adelino Ferreira and Mr. Mauricio V. da Costa. 
COELHO. P. M. Z.: MELLO, R. T. de \& TAVARES. C. A. P - Schistosoma mansoni: acquired resistarce in mice by implantation of yourg irradiated worms into the portal system Rev. Inst. Med trop. São Faulo, 31 (1): 14-17, 1989.

\section{REFERENCES}

i. BARBOSA, M. A. PELLEGRINO J; COELHO, P. M Z. \& SAMPAIO, I. B. M. - Quantitative aspects of the migration and evolutive asynchronism of Schistosoma mansoni in mice. Rev. Inst. Med. trop. S. Paulo, 20 $121-132,1978$

2. COELHO, P. M. Z; RASO, P: MELLO, R. T. HAR TRUNG, N.: TAVARES, C. A. P. \& ANTUNES, C. M. F - Schistosoma mansoni: durerenças entre cepas no hospe deiro vertebrado. In: INTERNATIONAI SYMPOSIUM ON SCHISTOSOMIASIS, 1.. Rio de Janeiro, Brazil, 1987. Abstracts. Abst. N: 132 .

3. DEAN, D A .... Schisiosoma and related genera: acquired resistance in mice A review. Exp. Parasit. 55: 1-104. 1983

4. DEAN, D A. - Sites of schistosome eiminatior. in: iN TERNATIONAL. SYMPOSIUM ON SCHISTOSOMIA SIS, 1. Rio de Janeiro, Brazil, 1987. Abstracts. Abst. N 1.34

5. DEAN, D. A ; CROLI, D \& BUKOWSKI R̂̃. A - Resis tance induced by normal and irradiated Sehistosoma mansoni: ability of various worm stages to serve as indu cers and targets in mice. Amer. J. trop. Med. Hyg., 30: 1026-1032,1981

6. FORD M J BICKLE Q D \& TAYLOR M G - ImmL nization of rats against Schistosoma mansoni using irra diated cercariae Iung schistosomula and liver-stage worms. Parasitology, 89:327-344, 1984

7. PELlegRINO, J.\& SIQUeira A. F. - Técnica de perfu sâo para colheita de Schistosoma manson em cobalas experimentalmente infestadas Rev. hras. Malar. 8:589.597, 1956

8. PHILLIPS, S. M \& COLLEY, D. G. - Immunologic as pects of host responses to schistosomiasis: resistance, im munopathology, and eosinophil involvement. Progr. Allergy, 24: 49-182, 1978.

9. PHILliPS, S M.; REID, W A \& SADUN, E. H. The cellular and humoral immune response to Schistosoma mansoni infection in inbred rats (II) Mechanisms during re-exposure. Cell. Immunol., 28: 75-89, 1977.

i0. ROCHA M. O. \& COELHO. P. M. Z, - The importance of skin and puimonary phases to the development of Schistosoma mansoni in albino mice. Rev. Inst. Med. trop. S. Paulo: 22: 157-163، [980.

11. SMITHERS, S. F \&OENHOFF M. -- Schisiosomiasis. In: COHEN, S \& W ARREN, K S - Immunity to parasitic infection. London, Blackwell, 1982

12. SMITHERS, S.R. \& TERRY. F. J. ... Immunity in Schisto. somiasis Ann. N. Y. Acad. Sci., 160: $826.840,1969$

13. W. H. O. Immunity in Scnistosomiasis. Bull Wla. Hlth. Org., 51: $553.595,1974$

Recebido para publicaçào em 06/6/1988 